$1-1-2020$

\title{
Welcoming Participation, Avoiding Capture: A Five-Part Framework
}

\author{
Melissa J. Durkee \\ Associate Dean for International Programs, Director of the Dean Rusk International Law Center \& Allen \\ Post Professor University of Georgia School of Law, mjdurkee@uga.edu
}

University of Georgia School of Law

Research Paper Series

Paper No. 2020-25

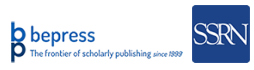

\section{Repository Citation}

Melissa J. Durkee, Welcoming Participation, Avoiding Capture: A Five-Part Framework, 114 Proc. of ASIL Ann. Mtg. 39 (2020),

Available at: https://digitalcommons.law.uga.edu/fac_artchop/1395

This Conference Proceeding is brought to you for free and open access by the Faculty Scholarship at Digital Commons @ University of Georgia School of Law. It has been accepted for inclusion in Scholarly Works by an authorized administrator of Digital Commons @ University of Georgia School of Law. Please share how you have benefited from this access For more information, please contact tstriepe@uga.edu. 


\section{BETWEEN PARTICIPATION AND CAPTURE: NON-STATE ACTOR PARTICIPATION IN INTERNATIONAL RULE-MAKING}

This panel was convened at 10:15 a.m., Thursday, June 25, 2020, by its moderator Ayelet Berman of the National University of Singapore, who introduced the panelists: Melissa ("MJ") Durkee of the University of Georgia School of Law; Igor Barbosa of the Ministry of Foreign Affairs - Brazil; Hassane Cisse, international development lawyer and former governance director of the World Bank Group; and Nancy Thevenin of the U.S. Council of International Business.

\section{Welcoming Participation, Avoiding Capture: A Five-Part Framework} doi:10.1017/amp.2021.6

\section{By Melissa J. Durkee*}

What role should non-state actors have in the work of international organizations? It is particularly fitting that this panel is titled "between participation and capture," because the phrase calls up the conflicting values that animate this question. When we think of non-state actors "participating" in the work of international organizations, we think about open, transparent organizations that are receiving the benefit of diverse perspectives and expertise. We may associate this phrase with process, access, and legitimacy in governance. On the other hand, when we think about non-state actors "capturing" the agenda of international organizations, we have a conflicting set of mental images: we imagine corruption, mission-drift, and the erosion of legitimacy in global governance. Openness is both valuable and dangerous.

\section{Costs And Benefits}

There are historical examples of both the value and the danger of participation by non-state actors, particularly the business actors that are the focus of this panel. As for dangers, the World Health Organization (WHO) has been the site of a number of battles. These include, for example, highly organized efforts by the tobacco industry. These were often covert, as the tobacco industry hid behind NGOs, academics, and developing-world farming associations to push their agenda. The WHO has also been the site of more recent struggles over sugar and pharmaceuticals. ${ }^{1}$ At the same time, industry representatives have been important contributors. They have been partners in organizations like UN Women, contributors to a balanced process in the International Labor Organization, and sources of expertise to improve lawmaking by the United Nations Commission on International Trade Law (UNCITRAL) and the International Institute for the Unification of Private Law (UNIDROIT), among others.

* Allen Post Professor, University of Georgia School of Law.

${ }^{1}$ See generally Ayelet Berman, Participation and Capture in International Rule-Making: The WHO Framework of Engagement with Non-state Actors (Jan. 15, 2020), available at https://ssrn.com/abstract=3592320 (describing the WHO's experiences with non-state actors and responsive reform efforts). 
As these examples suggest, industry representatives can have both positive and negative effects on international law and policymaking. Nevertheless, the area is understudied. Discussion about the rules governing non-state actor participation in international organizations has focused on how they govern classic "public interest" or "public benefit" organizations like Amnesty International, Greenpeace, or Doctors Without Borders. In fact, there was a great burst of enthusiasm about NGOs participating in global governance in the 1990s. This enthusiasm was exhibited by United Nations officials - urged on by Secretaries General Boutros Boutros-Ghali and Kofi Annan - and law review articles alike. The enthusiasm started to wane after the 1999 Battle of Seattle over the World Trade Organization, when NGOs started to critique some aspects of the multilateral post-war order. But there has neither been a corresponding rush of enthusiasm over the participation of industry and trade groups in global governance, nor sufficient critical analysis of their role in international institutions, even though these groups have been active alongside the NGOs all along. ${ }^{2}$

While the effect of industry and trade groups in global governance has been understudied and undertheorized, the literature does offer some observations. As for the benefits of this participation, it is clear that business representatives can offer expertise, develop technical standards, serve as essential stakeholders whose acceptance will be necessary to a rule's success, offer funding for important global projects, and serve as neutral parties to facilitate compromises between states. Potential harms include capture and other forms of subversion of the regulatory processes. Business participation in law and policymaking processes can give lobbyists a second bite at the apple, as they first lobby domestically to shape national policies, then take their positions directly to international bodies. Business participation in international organizations can exacerbate imbalances between the Global North and South or other geopolitical and economic disparities.

\section{A Five-Part Framework}

The challenge for anyone interested in effective global governance is to find a way to facilitate the benefits of business participation and restrain the potential harms. There is no silver bullet, or one-size-fits-all, solution. However, I will offer five factors I think we should be thinking about in developing future reforms. ${ }^{3}$

\section{A. Accountability to Mission}

First, reformers should consider accountability to mission. An organization with accountability to mission pursues that mission without getting derailed by special interests or other distractions or destabilizing forces. ${ }^{4}$ The mission need not be static. It can be subject to contestation, multifaceted, or evolving. But concerns about "capture" are concerns that the organization will begin to pursue the mission of certain special interests at the expense of its own. In designing reforms, the first question to address is what participatory structure will help organizations hew to their missions. Some organizations will have missions that demand more engagement with the private sector,

\footnotetext{
${ }^{2}$ See generally Melissa J. Durkee, Astroturf Activism, 69 StAn. L. Rev. 201 (2017) (examining this history).

${ }^{3}$ For a further development of these themes, see Melissa J. Durkee, Industry Groups in International Governance: $A$ Framework for Reform, 12 J. HuM. RTs. \& ENVT. _ (forthcoming 2021).

${ }^{4}$ See Dana Brakman Reiser \& Claire R. Kelly, Linking NGO Accountability and the Legitimacy of Global Governance, 36 BROOK. J. INT'L L. 1011, 1022 (2011) (defining accountability to mission as a duty: "the organization owes fealty to achieving its particular goals or purpose, i.e., its mission").
} 
others more protection from it. Accountability to mission is the consideration that demands variation among participation frameworks.

\section{B. Balance of Perspectives}

Second, reformers should evaluate whether the access rules facilitate a meaningful balance of perspectives. This is the value scholars are invoking when they call for the "democratization" of law and policymaking processes. Opening international organizations to input from a diversity of participants can also enhance the credibility and persuasive power of the resulting rules. To obtain these benefits, an access structure will need to ensure that the groups are actually in some sort of equilibrium, rather than dominated by a particular interest. Reformers should consider structures that can facilitate openness without falling into a variety of participation traps including imbalances between business and non-business groups, Global North and Global South groups, and between government delegates and non-state participants.

\section{Transparency}

Third, reformers should be alert to transparency. Many international access structures have tended to focus on representation over transparency. For example, the 1996 reforms at the Economic and Social Council (ECOSOC) required each participating organization to have a democratically adopted constitution, accountable representatives, and a representational process to set policy. These regulations may help ensure that an NGO speaks for a particular community of interest, but they do less to address the concerns associated with private sector lobbying. Guidelines related to lobbying tend to focus instead on transparency problems. For example, Organization of Economic Cooperation and Development guidelines on national lobbying regulation focus on disclosures about the objectives, beneficiaries, funding sources, and targets of lobbying activity. International reforms should follow suit. A lack of transparency can be harmful to the international law and policymaking process because this makes it more challenging for decisionmakers to weigh the merits of the input they receive.

\section{Meaningful Access}

Fourth, a participation structure should offer meaningful access. For the international law and policymaking process to obtain the benefits of participation by non-state groups - particularly legitimacy, information, and future cooperation - the participatory framework must offer these groups a meaningful ability to engage. At many international organizations, non-state actors have some informal participation rights like UN grounds passes, access to the agenda, perhaps some power to raise agenda items, and rights to sit in on meetings, but not much power to provide real input unless they secure places on national delegations. One way to give meaningful access is to give non-state actors roles in the decisional processes of the organization, as some modern multistakeholder organizations have done. However, robust participation by non-state actors should be balanced against the other factors offered in this framework - particularly accountability to mission and administrability, as discussed next.

\section{E. Administrability}

Fifth, and finally, participation structures should be evaluated for administrability. Is it feasible to ask gatekeepers to perform the tasks the participation structure requires? Consider accountability to mission. Is it feasible for officials to ferret out who or what interests a group represents? To the 
extent we want to divide and separately regulate business groups and other civil society groups, as the WHO's Framework of Engagement has attempted to do, do gatekeepers have enough information and bandwidth to do that effectively? This is an especially difficult challenge because many NGOs have partnerships or support by major corporations. If access frameworks try to balance perspectives or diminish conflicts of interest by treating separate categories of non-state actors differently, they may end up sending some business interests underground-reducing, rather than enhancing transparency. A better course may be for international organizations to use a less heavy-handed governance framework. Rather than examining a group's accountability to its membership, as the ECOSOC approach requires, and rather than policing a group's motives, as reforms at the WHO and Food and Agriculture Organization (FAO) try to do, a participatory structure might accept input from all sources, presuming that groups will advance a diversity of special interests, some profit motivated and some unrelated to profit. Potential conflict-of-interest issues could be mitigated through a structured notice-and-comment process, disclosure rules aimed at funding and lobbying positions, and publicly accessible databases that cast sunlight into the process.

\section{LOOKING AHEAD}

International access structures largely replicate the model of interaction between non-state actors and international organizations that existed in the League of Nations Era, which was incorporated without much deliberation into the United Nations framework at the end of World War II. In this model, non-state industry groups are on the same footing as groups pursuing other interests; all of these groups are considered helpers or "consultants" to international organizations. They are given participatory rights with very little screening or scrutiny, but these participatory rights are not all that significant. In the meantime, the world has changed. In the second half of the twentieth century, multinational enterprises rapidly multiplied and grew, and along with them, distrust of private agendas and power. Academics began to separate industry and trade representatives from a newly conceived category of "civil society" groups. The access rules at many international organizations did not mirror this shift, but some, like the WHO and FAO, implemented reforms to try to avoid the harms of capture and undue influence.

The early twenty-first century has ushered in a move toward welcoming greater business involvement in the work of international organizations. While concerns about lobbying, capture, and covert influence persist, these concerns exist alongside a second narrative that casts industry groups in more positive roles. The Sustainable Development Goals and the UN Guiding Principles on Business and Human Rights, for example, have sought to enlist business as partners in solving important global problems. Some of this momentum has been captured in new multi-stakeholder institutions that welcome business as equal partners. But the rise of those innovative organizations has done little to dislodge the standard working practices at many other international organizations.

What does this history suggest about how to strike the right balance between welcoming participation and avoiding capture going forward? Many current participation structures are better understood as products of path dependence than of careful deliberation. Their basic norms were developed a century ago, and have been slow to adjust to current needs and capacities. We should pay close attention to the experiences of the innovators, both those who are welcoming business representatives as robust participants or members, and those who are trying to contain and channel business influence: What is working, and what is not? Twenty-first century global governance structures should be nimble and responsive to current needs, not path dependent, because there is simply nothing inevitable about the current access rules. These access and participation frameworks should therefore not serve as a limitation but as a reference point for future structures, which should accommodate present and future needs. 